\title{
Radiological, Clinical, and Histological Findings in the Treatment of Pilonidal Sinus with Phenol Injection
}

\section{Fenol Enjeksiyon ile Pilonidal Sinüs Tedavisinde Radyolojik, Histolojik ve Klinik Bulgular}

\author{
(1) Tonguc Utku YILMAZ1, (1) Omer YAVUZ2, (1) Ahmet Oktay YIRMIBESOGLU2, (1) Hasan Tahsin SARISOY3, \\ (1) Cigdem VURAL4, (1) Umay KIRAZ4 , (1) Nihat Zafer UTKAN2
}

'Acibadem Mehmet Ali Aydinlar University Atakent Hospital, Organ Transplantation Unit, Istanbul, Turkey

2Kocaeli University Faculty of Medicine, Department of General Surgery, Kocaeli, Turkey

${ }^{3}$ Acibadem Kocaeli Hospital, Clinic of Radiology, Kocaeli, Turkey

${ }^{4}$ Kocaeli University Faculty of Medicine, Department of Pathology, Kocaeli, Turkey

\begin{abstract}
Objective: Sacrococcygeal pilonidal disease is a chronic discharging wound that causes pain and loss of quality of life. Phenol application is an outpatient procedure with low complications and low recurrence rates. We evaluated the radiological, histological, and clinical results of phenol application.

Methods: A total of 44 consecutive patients with sacrococcygeal pilonidal disease underwent phenol application in Kocaeli University Faculty of Medicine, General Surgery Clinic between December 2015 and March 2017. Demographics, complaints, symptom duration, and the number of sinuses were recorded. Patients were examined using ultrasonography (USG) before surgery and two months after surgery. Four patients who wanted rhomboid excision and Limberg flap procedure underwent preoperative local phenol application and were excluded from the study. The excised tissues were used for pathological evaluation.

Results: Purulent discharge was the leading symptom. All of the patients had hair in the preoperative USG evaluation, whereas five patients had still hairs in the sinuses in the postoperative USC examination. Four of these cases had recurrences on a 2-month follow-up. After phenol application, a 10\% volume decrease was observed. Pathological examination was performed in four cases with phenol application, and in pathological material, the sinuses looked sclerotic and fibrotic

Conclusions: Our study revealed that a single phenol application achieved $90 \%$ success. However, no significant difference was observed in the cavity volume after phenol injection.

Keywords: Pilonidal sinus, phenol, ultrasonography, histology
\end{abstract}

\section{öz}

Amaç: Pilonidal sinüs ağrıya neden olan, hayat kalitesini bozan kronik akıntılı bir yaradır. Fenol uygulanması düşük komplikasyon oranı, düşük tekrarlama oranı ile poliklinik şartlarında yapılabilen bir uygulamadır. Bu çalışmada fenol uygulamanın radyolojik, histopatolojik ve klinik sonuçları verilmiştir.

Yöntemler: Kocaeli Üniversitesi Tıp Fakültesi, Genel Cerrahi Kliniği'nde Aralık 2015 ve Mart 2017 tarihleri arasında sakrokoksigial pilonidal sinüs nedeniyle fenol uygulanan 44 hasta çalışmaya alındı. Hastaların demografik bilgileri, şikayetleri, semptom süreleri, sinüs ağız sayıları not edildi. Hastala işlem öncesi ve işlemden 2 ay sonra ultrasonografi (USG) ile değerlendirildi. Fenol uygulması yapılan 4 hasta rhomboid eksizyon ve Limberg flap işlemi istediği için çalışma dışı bırakıldı. Çıkarılan dokular histolojik incelemeye alındı.

Bulgular: Akıntı en sık semptomdu. Tüm hastaların fenol ișlem öncesinde yapılan USG incelemesinde sinüs içinde kıl görüldü. İşlem sonrası incelemede sinüs içinde 5 hastada hala kıl izlendi. Bu hastalardan $4^{\prime}$ ü işlem sonrası 2. ayda nüks ile başvurdu. USG incelemede sinüs kavitesi ortalama $\% 10$ azalmıştı. Histolojik incelemede sinüs dokusunda skleroz ve fibroz izlendi.

Sonuçlar: Bu çalışmada tek doz fenol uygulaması \%90 başarı elde etmiştir. Fenol uygulaması ile sinüs hacminde belirgin değişiklik olmamıştır. Anahtar kelimeler: Pilonidal sinüs, fenol, ultrasonografi, histoloji
Address for Correspondence: T. U. Yilmaz, Acibadem Mehmet Ali Aydinlar University Atakent Hospital, Organ Transplantation Unit, Istanbul, Turkey

E-mail: drutkuyilmaz@yahoo.com ORCID ID: orcid.org/0000-0002-2344-7783
Received: 22 October 2021

Accepted: 17 January 2022

Online First: 25 January 2022

Cite as: Yilmaz TU, Yavuz O, Yirmibesoglu AO, Sarisoy HT, Vural C, Kiraz U, Utkan NZ. Radiological, Clinical, and Histological Findings in the Treatment of Pilonidal Sinus with Phenol Injection. Medeni Med J 2022;37:29-35

${ }^{\odot}$ Copyright 2022 by the Istanbul Medeniyet University / Medeniyet Medical Journal published by Galenos Publishing House.

Licenced by Creative Commons Attribution-NonCommercial 4.0 International (CC BY-NC 4.0) 


\section{INTRODUCTION}

Sacrococcygeal pilonidal disease (PD) is a chronic discharging wound of the natal cleft that causes pain and loss of working time and quality of life $e^{1,2}$. The ideal treatment of PD should be simple, cost effective, and is preferably administered in an outpatient setting under local anesthesia, thereby leading to minimal discomfort, less time off, and low recurrence rates. Phenol application is a simple outpatient procedure with low complications and low recurrence rates ${ }^{3}$.

Phenol is an aromatic compound and is a corrosive agent for an extensive tissue protein denaturation ${ }^{4}$. The main aim of phenol treatment includes cavity infection sterilization, hair, and cellular debris removal, and sinus epithelium destruction without sinus extraction ${ }^{5}$. After phenol application, the sinus cavity was still present but clinical symptoms were resolved. There's still contraversion about the clinical improvements with the existence of cavities. Beyond the sinus cavities, the sulcus of the natal cleft was blamed for the mechanism of PD. Tezel et al. ${ }^{6}$ revealed that the main target of PD treatment is explained by natal cleft flattening. Natal cleft flattening without clearing the sinuses achieved high success in the previous study ${ }^{6}$. The success of phenol application is probably the histological changes. Without removing the sinus cavities, the shrinkage amount of the sinus cavity after phenol application is unknown. Changes that occur after phenol application are unclear in the literature. Histological and radiological changes are gaining importance in phenol treatment.

Thus, this study aimed to evaluate the radiological, histological, and clinical results of phenol application.

\section{MATERIALS and METHODS}

This prospective clinical case series was approved by the Kocaeli University Clinical Research Ethics Committee with the protocol number KAEK 2015/48 (date:10.03.2015). Written informed consent was obtained from the patients. The study was performed between December 2015 and March 2017 in the Department of General Surgery, Faculty of Medicine, Kocaeli University. Patients were selected from the outpatient department and were examined by the senior resident (O.Y.) and referred from the outpatient clinic to the responsible investigators (TUY, OY, NZU), consecutively. Patients who suffer from pain and pus discharge from the natal cleft at the top of the buttocks were selected for the treatment. Patients with previous surgical treatment, recurrent cases, autoimmune diseases, acute pilonidal abscess, loss to follow-up, and hidradenitis suppurative were excluded from the study. Age, sex, body mass index (BMI), complaints, symptom duration, and the number of sinuses were recorded. Based on patient history and clinical findings, PD is classified according to the navicular area concept ${ }^{7}$. Only type III cases were included in the study. Patients were examined using ultrasonography (USG) before the surgery and 2 months after the surgery. Examinations were performed using a $7.5-\mathrm{MHz}$ linear probe with a LOGIQ 5 pro ultrasound scanner (General Electric, USA). According to the USG evaluation, the existence of hair and the largest three dimensions (length, width, and depth) were obtained. All scannings were performed by two radiologists. Approximate volume was calculated by multiplying the length of the largest three dimensions by 0.5 . The rates of pre- and postadministration volume differences were calculated [(Prevolume - Post-volume)/Pre-volume] to see the volume changes after phenol treatment. Four patients wanted rhomboid excision and Limberg flap procedure after the local phenol application since their relatives who had suffered from pilonidal sinus have been improved by other surgical techniques. Previous successful treatment history of their relatives had influenced the decision of the patients. These four patients were followed up and the histological results were obtained. The excised tissues were sent for pathological evaluation. They were histologically evaluated for phenol effects. The pathological specimens of two cases with Rhomboid excision and Limberg flap without phenol application were examined to histologically compare with phenolapplied specimens. These pathological specimens were obtained from our previously operated cases.

The procedures were performed in the local operation room. Neither bowel preparation nor antibiotic prophylaxis was used. Patients were placed in a prone position during the procedure, without sedation. The buttocks were shaved just before the procedure and the skin was cleaned with antiseptic solution (Batticon). Local anesthesia (Jetokain, Adeka Pharmaceutical Industry, Istanbul) was administered to the pilonidal sinus opening, and the sinus openings were widened by dilating it using a clamp (BH-109 Aesculap, Aescuplap Werke AG, Tutlingen, Germany). In patients with more than one sinus opening, the same procedure was separately performed for each opening. Curettage was performed for debris and hair removal. Liquid phenol (with a concentration of $80 \%$ ) was administered to the sinus using a syringe and was held for $2 \mathrm{~min}$. The skin tissue that surrounds the sinus opening was protected with nitrofurantoin ointment (Furacin, Eczacibasi Pharmaceutical Industry and Trade Inc, Istanbul, Turkey) against the caustic and irritant phenol effects. Then, the sinus was washed out with 
saline against phenol leakage to the skin. Patients were discharged from the hospital on the same day when the procedure was completed, and they were suggested to clean the treatment site. Patients were allowed to return to work on the following day and were followed up in the outpatient department as 2 and 12 months. Recurrent cases underwent further debridement and received phenol readministration. Lack of symptoms, such as pus discharge, pain, and erythema, was considered a clinical success.

\section{Statistical Analysis}

The obtained results were expressed in mean \pm standard deviation. The recurrent cases were limited, thus no comparison was performed.

\section{RESULTS}

A total of 44 consecutive patients with sacrococcygeal PD underwent phenol application in the study. The characteristics of patients are shown in Table 1. All patients had hair in the preoperative USG evaluation (Figure 1). The postoperative USG examination on the second month revealed hairs in the sinuses of five patients. Four of these cases had symptoms of purulent discharge and pain at 2 months follow-up. Four cases were considered as recurrence and underwent hair removal and phenol reapplication. In the follow-up, recurrent cases improved in the second month. Skin necrosis, fatty tissue necrosis, or abscesses were not observed in our cases. In 1 year follow-up, recurrence or complications were not observed in any of the patients. The USG follow-up revealed only a $10 \%$ volume decrease after phenol administration. No patients were lost to follow-up.

Four cases underwent rhomboid excision and Limberg flap for surgical repair of the pilonidal sinus
2 months after phenol administration. Pathological examination was performed in four cases together with phenol administration, and the sinus tracts were opened in macroscopic sections (Figure 2). Pilonidal sinuses were completely excised. The sinuses were hard in macroscopic terms and seemed fibrotic. Neither purulent discharge nor apparent hairs were observed in the sinuses. The histological examination of the sinus tracts revealed active chronic inflammatory granulation tissues (Figure 3). The presence of epithelization along the sinus tract was noted in four cases. A trace amount of hair shafts were seen in the microscopic examination (Figure 3). Pathological specimens of previous cases, which underwent rhomboid excision and Limberg flap only without phenol, were reevaluated for histological findings. These previous cases have foreign body-type reactions of giant cells, debris, lots of hair shafts, and active chronic inflammatory granulation tissue (Figure 4).

\begin{tabular}{|c|c|}
\hline & Data \\
\hline Mean age (years $\pm S D$ ) & $26.3 \pm 3.4$ \\
\hline Female/male & $2 / 38$ \\
\hline Mean BMI kg/m² & $25.7 \pm 2.3$ \\
\hline \multicolumn{2}{|l|}{ Complaints (n) } \\
\hline Purulent discharge (n) & 40 \\
\hline Bleeding (n) & 18 \\
\hline Itching (n) & 36 \\
\hline Length of symptoms (years \pm SD) & $1.5 \pm 0.4$ \\
\hline Mean number of sinus openings ( $n \pm$ SD) & $1.3 \pm 0.2$ \\
\hline Mean downsizing volume ratio of the sinus & $\begin{array}{l}10.6 \% \\
\text { downsizing }\end{array}$ \\
\hline Recurrence cases (n) & 4 \\
\hline \multicolumn{2}{|c|}{ n: Number, SD: Standard deviation, BMI: Body mass index } \\
\hline
\end{tabular}

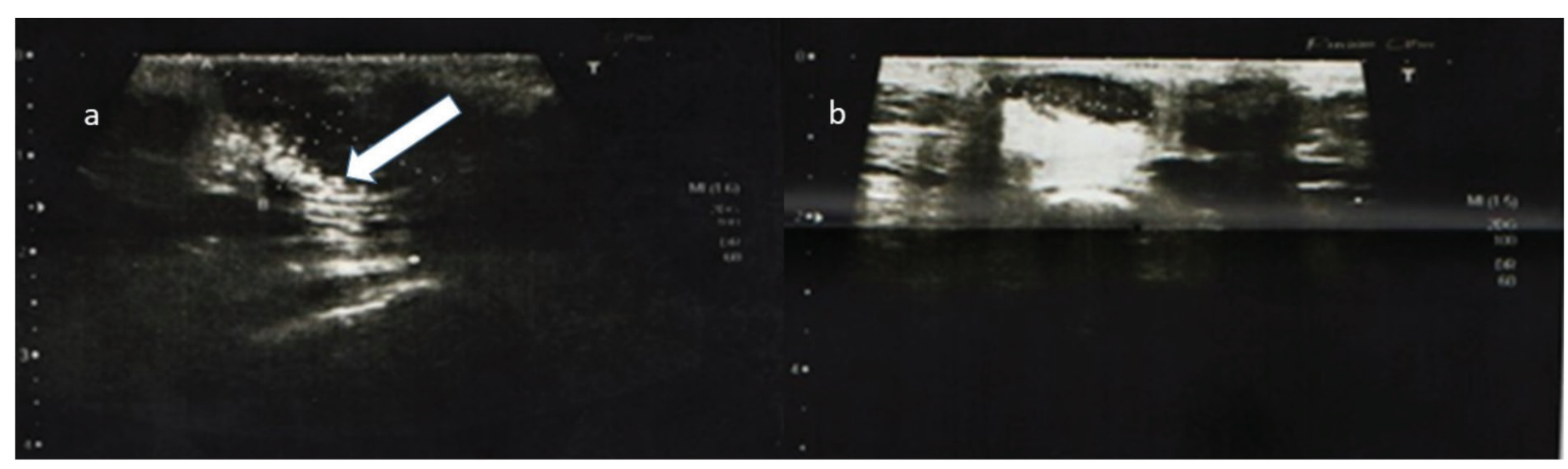

Figure 1. Preoperative ultrasonographic pilonidal sinus evaluation. Three dimensions of the sinus cavity were measured.

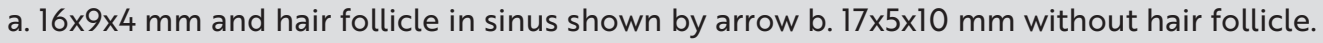




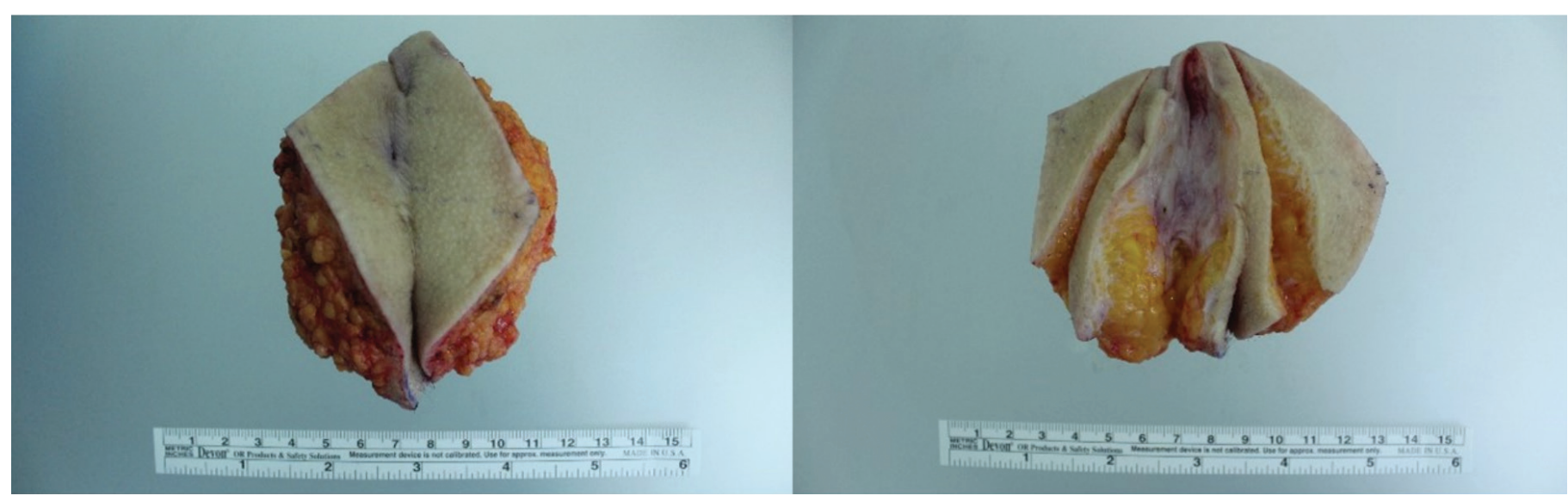

Figure 2. Pathological specimen of rhomboid excision. Sliced specimen showing chemical debrided sinus.

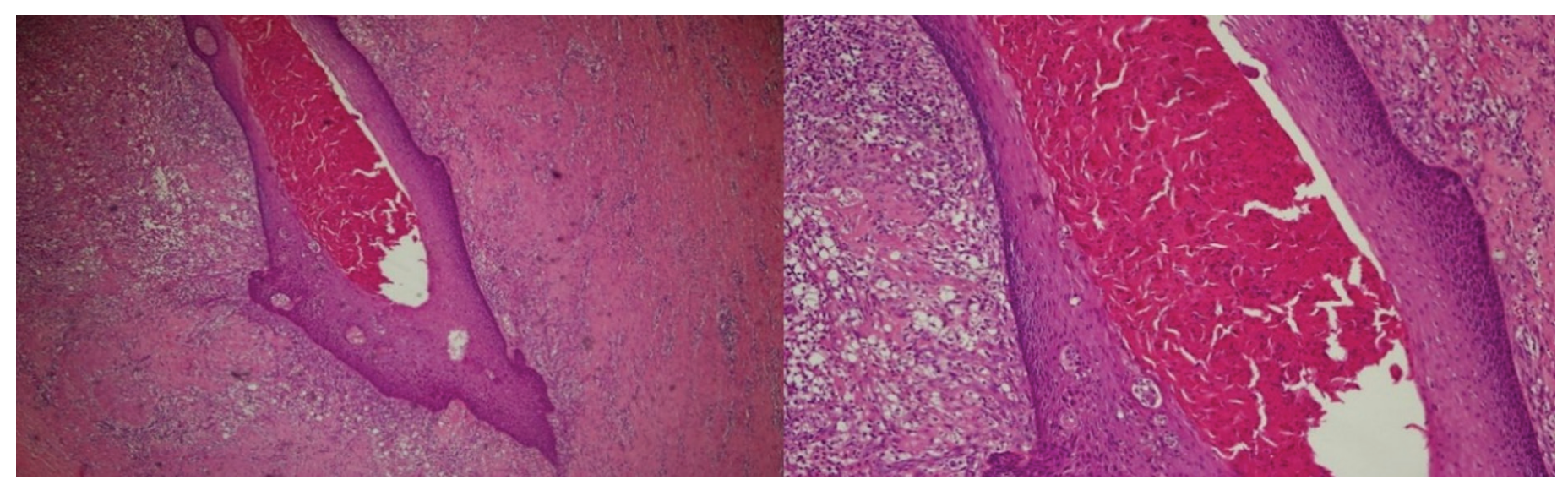

Figure 3. Microscopic evaluation of pilonidal sinuses of patients with phenol application. Significant epithelization is seen without hair in the phenol application (H\&E, 40x, and 100x).

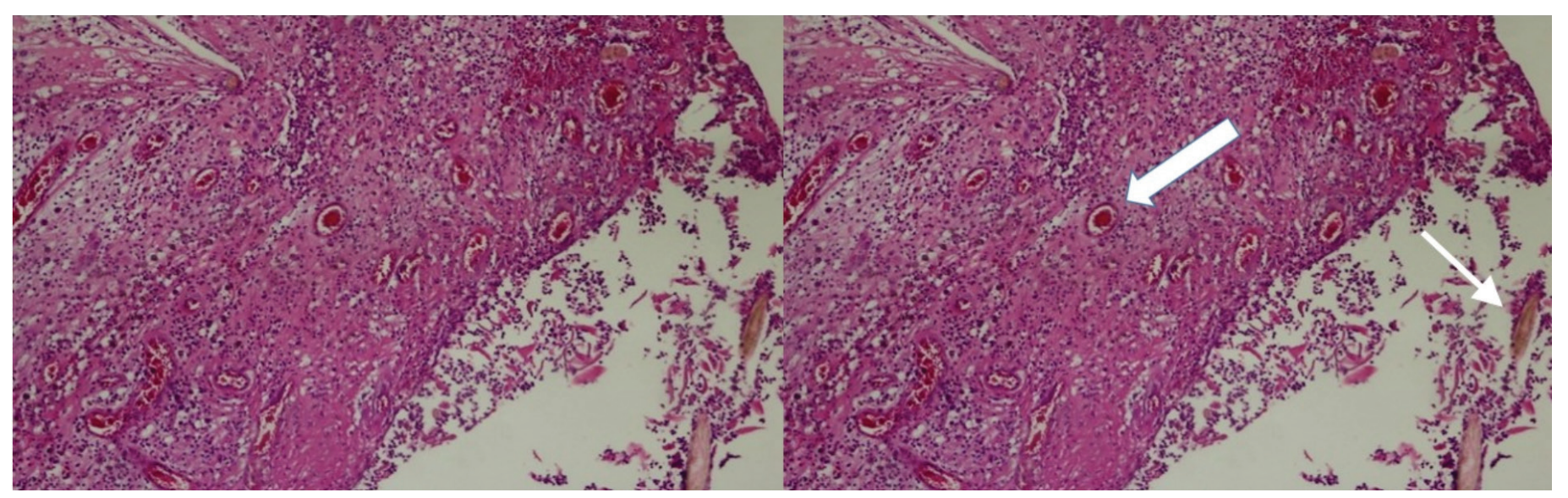

Figure 4. Microscopic evaluation of patients with rhomboid excision and Limberg flap. Hair shafts, pseudoepitheliomatous hyperplasia, and trace amount epithelization in the sinus tracts of patients without phenol application. (H\&E, 100x). Hair shafts were shown by a thin white arrow. Pseudoepitheliomatous hyperplasia was shown by a thick white arrow. 
However, epithelization was not observed in the pilonidal sinus tracts without any phenol administration.

\section{DISCUSSION}

Our study revealed that phenol administration has a high clinical success rate with $10.6 \%$ pilonidal sinus cavity shrinkage. The possible mechanism for clinical improvement might be pilonidal sinus cavity epithelization. Pilonidal sinus disease is presented by a chronic discharging wound. There are two entities including infectious findings and wound. Infectious findings are purulent discharge, abscess, pain, itching, etc. Most treatment protocols are performed after infection elimination ${ }^{8}$. Wound findings include volumes of sinus cavities, numbers of openings, and distances of openings to the natal cleft. Tezel et al. ${ }^{6}$ made a classification based on infectious history and sinus openings in the navicular area. According to this classification, type III is composed of sinus openings in the navicular area with previous infectious findings. Our study excluded cases with acute pilonidal abscess (type II), recurrent (type V), extensive (type IV), and asymptomatic cases (type I). This study had a limited number of sinus openings. None of the cases have $>3$ openings, and all cases were in the navicular area. Phenol is an aromatic hydrocarbon that is derived from coal tar and was originally used in the treatment of sewage?. Phenol is corrosive to human skin. Coagulation necrosis in phenol treatment is rapid and continues to penetrate the tissue with its high lipid solubility ${ }^{10}$. Despite toxic side effects, it has gained widespread usage in pilonidal sinus treatment.

Various local phenol treatment techniques have been mentioned $^{8}$, such as single or multiple applications, endoscopic, punch excision, crystallized, or liquid ${ }^{2,11,12}$. Nearly all of the treatments achieved $>90 \%$ success rate with a low complication rate and nearly 4 days to return to work ${ }^{2}$. The single application in our study achieved a $90 \%$ success rate in the second month. This short-term follow-up was enough to realize the recurrent cases. With the second application, recurrent cases were also healed and achieved a $100 \%$ success rate after 2 months. Neither recurrence nor complication was observed 1 year after the procedure. Long-term follow-up also showed a high success rate. All patients returned to work the day after the first and second phenol injection sessions. The early return to work in our study is an important achievement of phenol treatment. The number of sinuses, cavity volume, abscess drainage history, and remaining hair were shown to be the factors for recurrences in the previous studies ${ }^{1,3}$. However, in our study, all recurrent cases have remaining hair in the openings. Thus, cleaning the hair before phenol administration is important. USC has been used in some studies for the remaining hair in the openings to decrease the recurrences ${ }^{13,14}$. Sinus extensions were determined by USG and exact excision of drainage was performed ${ }^{13}$. USG was revealed effective in the pilonidal sinus treatment. Our study used USC for volume changes; however, we realized that the remaining hairs, which are risk factors for recurrences, are seen by USG. Kaymakcioglu et al.' determined the volumes of sinuses by fluid application, which gave exact volume as the USG measurement. This method is more accurate than USG, but our study aimed to observe the volume changes rather than the volume measurement and observe possible changes. This study revealed that the sinus remained without significant volume change, but with symptom improvement. A little amount of shrinkage was observed. The remaining sinuses do not produce pilonidal sinus symptoms. In this case, histological changes due to the application seem to be beneficial for the treatment.

Previous studies revealed that the pilonidal sinus contained debris, hair, and granulation tissue that is surrounded by fibrous tissue with inflammation ${ }^{15}$. Granulation tissue, inflammation, and keratin plugs were observed in most of the cases; however, epithelization was only seen in $4 \%$ in the study of Sondenaa and Pollard ${ }^{15}$. Granulation of the sinus is infiltrated by neutrophils, lymphocytes, plasma cells, and sometimes, haemosiderin-laden macrophages ${ }^{16}$. An expansion with a chronic abscess cavity in the lower dermis and subdermal tissues occurr. ${ }^{16}$ Coagulation necrosis is mentioned for the mechanism of action in phenol treatment; however, this was not observed in the present study. Coagulation necrosis might be the primary action, but patients underwent operation 2 months after the phenol treatment in our study. Large numbers of mostly rootless hair with cut ends were found inside the sinus cavities ${ }^{17}$. Short hair appears to be more capable of penetrating the sinus, thereby causing further inflammation. Rootless hair had a three times greater probability of entering into the sinus or leading to inflammation than hair with its root in the sinus ${ }^{17}$. Sharp ends penetrate the skin and embed in the granulation tissue. Hair existence as foreign material in the sinus cavity leads to the continuation of inflammation and granulation. Hair removal and sinus wall curettage just before phenol administration help clear the foreign materials and inflammatory cellular debris. According to the previous literature and our findings, the hair in the sinus is an important factor for recurrence and continuous inflammation. Rootless hair, which is coming out of the sinus, is also a risk factor for inflamation ${ }^{17}$. 
However, long-term results of phenol treatment also revealed no recurrences. Therefore, epithelization is also protective against the inflammatory effect of hairs coming out from the sinuses ${ }^{18}$. With the presence of an infection, treating the patient with antibiotics is better before the procedure since acute inflammation would inhibit the epithelization effect of phenol. After phenol administration, sinus wall epithelization occurs. The essential feature of a healed wound is the restoration of an intact epidermal barrier through wound epithelization ${ }^{19}$. Sinus cavity epithelization prevents infectious clinical findings. This is how phenol achieved its success.

Several surgical techniques have been mentioned in the previous studies ${ }^{6}$. Of which, the main target was based on navicular area flattening, sinus curettage, etc. All these procedures not only eliminate the sinuses but also reconstruct the sacrococcygeal area. However, the main target in phenol administration is the lining of sinuses.

The ideal treatment of PD should be simple, cost effective, and preferably performed in an outpatient setting under local anesthesia with minimal discomfort, time off work, and a low recurrence rate. Phenol application has high success but with limited knowledge in histological and radiological outcomes. Phenol application leads to sinus wall epithelization. Volumes of the sinuses significantly remained after phenol application. Clinical improvement is achieved after phenol application.

The limitations of our study are the inclusion of only type 3 PD and the limited number of histological evaluations of cases that are treated with phenol.

\section{CONCLUSIONS}

The ideal treatment of PD should be simple, cost effective, and preferably performed in an outpatient setting under local anesthesia with minimal discomfort, time off work, and low recurrence rates. After phenol application, clinical improvements, such as the absence of purulent discharge, itching, and infection findings, were observed in short- and long-term follow-up. Phenol application has a high success rate but with limited knowledge in its histological and radiological outcomes. The most important point of this study is the sinus wall epithelization after phenol injection. By this epithelization, no recurrence was observed in any of the patients. Additionally, patients underwent phenol injection for the second time since not all hairs could be removed in the first injection, and therefore, complete epithelization did not develop. Volumes of sinuses significantly remain after phenol application. The existence of epithelized sinus after phenol administration achieved clinical success.

\section{Ethics}

Ethics Committee Approval: This prospective clinical case series was approved by the Kocaeli University Clinical Research Ethics Committee with the protocol number KAEK 2015/48 (date: 10.03.2015).

Informed Consent: Written informed consent was obtained from the patients.

Peer-review: Externally and internally peerreviewed.

\section{Author Contributions}

Concept: T.U.Y., O.Y., A.O.Y., N.Z.U., Design: T.U.Y., O.Y., A.O.Y., N.Z.U., Data Collection and/or Processing: T.U.Y., O.Y., H.T.S., C.V., U.K., Analysis and/or Interpretation: T.U.Y., A.O.Y., H.T.S., C.V., U.K., N.Z.U., Critical Revision: T.U.Y., H.T.S., N.Z.U., Writing: T.U.Y., O.Y., A.O.Y., C.V., U.K.

Conflict of Interest: The authors have no conflict of interest to declare.

Financial Disclosure: The authors declared that this study has received no financial support.

\section{REFERENCES}

1. Kaymakcioglu N, Yagci G, Simsek A, et al. Treatment of pilonidal sinus by phenol application and factors affecting the recurrence. Tech Coloproctol. 2005;9:21-4.

2. Kayaalp C, Aydin C. Review of phenol treatment in sacrococcygeal pilonidal disease. Tech Coloproctol. 2009;13:189-93.

3. Dag A, Colak T, Turkmenoglu O, Sozutek A, Gundogdu R. Phenol procedure for pilonidal sinus disease and risk factors for treatment failure. Surgery. 2012;151:113-7.

4. Luttrell WE. Toxic tips: Phenol. Chem Heal Saf. 2003;10:20-1.

5. Maurice BA, Greenwood RK. A conservative treatment of pilondidal sinus. Br J Surg. 1964;51:510-2.

6. Tezel E, Bostancı H, Anadol Z, Kurukahvecioğlu O. Cleft Lift procedure for Sacrococcygeal Pilonidal Sinus. Dis Colon Rectum. 2009;52:135-9.

7. Tezel E. A new classification according to navicular area concept for Sacrococcygeal Pilonidal disease. Colorectal Dis. 2007;9:5756.

8. Kober MM, Alapati U, Khachemoune A. Treatment options of pilonidal sinus. Cutis. 2018;102:E23-29.

9. Sozuer EM, Topel U, Dal F, Akyuz M, Talih T. Application of crystalline phenol in pilonidal sinus disease A single-center and singlesurgeon experience. Ann Ital Chir. 2020;91:520-5.

10. Sugden P, Levy M, Rao CS. Onychocryptosis-Phenol burn fiasco. Burns. 2001;27:289-92. 
11. Gecim IE, Goktug UU, Celasin H. Endoscopic Pilonidal Sinus Treatment Combined with Crystalized Phenol Application May Prevent Recurrence. Dis Colon Rectum. 2017;60:405-7.

12. Demirel AH, Polat M. Long-Term Outcomes of Crystallized Phenol Application after Punch Excision for the Treatment of Pilonidal Sinus Disease. Am Surg. 2019;85:1219-23.

13. Smart PJ, Dungerwalla M, Heriot AG. Bascom's Simple Pilonidal Sinus Surgery: Simpler with Ultrasound Guidance. J Med Ultrasound. 2013;21:97-9.

14. Mentes O, Oysul A, Harlak A, Zeybek N, Kozak O, Tufan T. Ultrasonography accurately evaluates the dimension and shape of the pilonidal sinus. Clinics (Sao Paulo). 2009;64:189-92.

15. Sondenaa K, Pollard ML. Histology of chronic pilonidal sinus. APMIS. 1995;103:267-72.
16. Chintapatla S, Safarani N, Kumar S, Haboubi N. Sacrococcygeal pilonidal sinus: historical review, pathological insight and surgical options. Tech Coloproctol. 2003;7:3-8.

17. Bosche F, Luedi FM, van der Zypen D, Moersdorf P, Krapohl B, Doll D. The Hair in the Sinus: Sharp-Ended Rootless Head Hair Fragments can be Found in Large Amounts in Pilonidal Sinus Nests. World J Surg. 2018;42:567-73.

18. Dogru O, Kargin S, Turan E, Kerimoglu RS, Nazik EE, Ates D. Long-term outcomes of crystallized phenol application for the treatment of pilonidal sinus disease. J Dermatolog Treat. 2020;19:1-8.

19. Pastar I, Stojadinovic O, Yin NC, et al. Epithelialization in Wound Healing: A Comprehensive Review. Adv Wound Care (New Rochelle). 2014;3:445-64. 